\title{
Rhinocerotidae and Chalicotheriidae (Perissodactyla, Tapiromorpha)
}

\author{
Pierre-Olivier ANTOINE \\ Institut des Sciences de l'Évolution de Montpellier, UMR 5554 CNRS/UM/EPHE, \\ UR226 IRD, c.c. 64, Université de Montpellier, Place Eugène Bataillon, \\ F-34095 Montpellier cedex 05 (France) \\ pierre-olivier.antoine@umontpellier.fr \\ Sevket SEN \\ CR2P UMR 7207 (MNHN, CNRS, UPMC, Sorbonne Universités), \\ Département Histoire de la Terre, Muséum national d'Histoire naturelle, \\ case postale 38, 57 rue Cuvier, F-75231 Paris cedex 05 (France) \\ sen@mnhn.fr
}

Published on 24 June 2016

KEY WORDS

Rhinocerotidae,

Chalicotheriidae,

reworked Ronzotherium

late Vallesian,

Istanbul region,

paleobiogeography.

Antoine P.-O. \& Sen S. 2016. - Rhinocerotidae and Chalicotheriidae (Perissodactyla, Tapiromorpha), in Sen S. (ed.) Late Miocene mammal locality of Küçükçekmece, European Turkey. Geodiversitas 38 (2): 245-259. http://dx.doi. org/10.5252/g2016n2a6

\section{ABSTRACT}

Here we describe mandibular, dental, and postcranial remains referable to Rhinocerotidae and Chalicotheriidae (Perissodactyla) originating from the vertebrate localities of Küçükçekmece East and Küçükçekmece West, in Thrace (European Turkey). The four rhinocerotids recognized comprise the early diverging Ronzotherium sp. (one lower molar, reworked from Oligocene deposits; Küçükçekmece West), the two-horned rhinocerotine Ceratotherium neumayri (Osborn, 1900), and two small chilothere aceratheriines: Chilotherium schlosseri (Weber, 1905) and Persiatherium sp. A chalicotheriine chalicotheriid, Kalimantsia sp., is documented by two tooth fragments and an unfused second phalanx of undoubtful affinities in Küçükçekmece West. This occurrence substantiates the record of Kalimantsia, previously restricted to the type locality Kalimantsi-Pehsata, in SW Bulgaria, and allows notably for the first recognition of postcranial remains for this taxon. Although distinct in terms of taxonomic composition and relative abundance, the rhinocerotid assemblages of Küçükçekmece East and Küçükçekmece West are in total agreement with a single biostratigraphical age, estimated to be correlated with the late Vallesian MN10 zone. 
MOTS CLÉS

Rhinocerotidae, Chalicotheriidae, Ronzotherium remanié, Vallésien supérieur, région d'Istanbul, paléobiogéographie.

\section{RÉSUMÉ}

Rhinocerotidae et Chalicotheriidae (Perissodactyla, Tapiromorpha).

Nous décrivons ici des restes mandibulaires, dentaires et postcrâniens de Rhinocerotidae et de Chalicotheriidae (Perissodactyla) provenant des localités du Miocène supérieur de Küçükçekmece Est et Küçükçekmece Ouest, en Thrace (Turquie d'Europe). Les quatre rhinocérotidés reconnus sont la forme basale Ronzotherium sp. (une molaire inférieure, remaniée de dépôts oligocènes; Küçükçekmece Ouest), le rhinocérotiné bicorne Ceratotherium neumayri (Osborn, 1900) et deux acérathériinés chilothères de petite taille: Chilotherium schlosseri (Weber, 1905) et Persiatherium sp. Un chalicothériidé chalicothériiné est représenté à Küçükçekmece Ouest par deux dents fragmentaires et une deuxième phalange de la main non fusionnée. Ces restes, attribués à Kalimantsia sp., étendent la répartition stratigraphique et géographique du genre, jusqu'alors restreinte à la localité type de Kalimantsi-Pehsata (Turolien de Bulgarie), et documentent pour la première fois un élément du squelette appendiculaire de ce chalicothériiné. L'assemblage de rhinocérotidés de Küçükçekmece (Est + Ouest) correspond parfaitement avec l'âge biostratigraphique Vallésien supérieur (MN10), tel que consensuellement indiqué par les autres groupes de mammiferes.

\section{INTRODUCTION}

Perissodactyls are conspicuous elements of Miocene faunas in Eurasia. Among them, tapiromorphs (rhinocerotids and chalicotheriids, plus tapirids), usually co-occur along with hippomorphs (equids). These megaherbivores were living in a wide array of environments, ranging from savannahs to swamps and from forests to steppes of Eurasia, North America, and Africa before their decline by Pliocene-Pleistocene times (Heissig 1975; Agustí \& Antón 2002: 211-213; Mirzai Atabaadi et al. 2013).

Here we describe mandibular, dental, and postcranial remains referable to Chalicotheriidae and Rhinocerotidae, and originating from the upper Miocene localities of Küçükçekmece East and Küçükçekmece West, in Thrace (European Turkey). The locality of Küçükçekmece East is the one initially excavated by Malik \& Nafiz (1933) who described among other vertebrates some rhinocerotids from this locality (see also Sayar 1953). The fossils from this locality are stored at the Technical University of Istanbul (Yalçınlar 1954). Küçükçekmece West is actually a layer that crops out along the western shores of the Küçükçekmece Lagoon, of which Father Jean Nicolas (1978) collected outcropping fossils during 1950s and 1960s. The specimens from this locality are stored at the Muséum national d'Histoire naturelle in Paris (see Sen 2016a). Geological features of the region and stratigraphy of sedimentary units are studied by Lom et al. (2016) and several groups of mammals from the same localities are described in the other articles of this volume (Proboscidea by Tassy [2016]; Carnivora by Peigné [2016]; Equidae by Koufos \& Sen [2016]; Artiodactyla by Kostopoulos \& Sen [2016]; rodents, lagomorphs and insectivores by Sen [2016b]).

\section{MATERIAL AND METHODS}

The material is stored in the collections of both the Istanbul Technical University (specimens numbered KÇ from Küçükçekmece East) and the Muséum National d'Histoire Naturelle, in Paris (specimens numbered TRQ from Küçükçekmece West). The material from Küçükçekmece West includes a lower molar of Ronzotherium Aymard, 1854. This lower molar may well be derived from Oligocene deposits that crop out in the same region below the Miocene deposits. It is included in this study, knowing however that it does not belong to the late Miocene Küçükçekmece fauna.

Dental terminology is that of Heissig (1972: pl. 13) and Antoine (2002) for rhinocerotids, and that of Coombs (1989) for chalicotheriids. Anatomical features for rhinocerotids follow basically the same sequence as in Antoine (2002), and Antoine et al. (2010), with addings from Lu (2013) and Pandolfi (2016) regarding aceratheriines. Suprageneric systematics follows the arrangement proposed by Antoine et al. (2010), Becker et al. (2013), and Lu (2013) for rhinocerotids, and Anquetin et al. (2007) for chalicotheriids. Dimensions are given in mm.

\begin{tabular}{ll}
\multicolumn{2}{l}{ ABBREVIATIONS } \\
Anatomical abbreviations \\
I & upper incisor; \\
D & upper deciduous; \\
P & upper premolar; \\
M & upper molar; \\
i & lower incisor; \\
d & lower deciduous; \\
p & lower premolar; \\
m & lower molar; \\
ant & anterior; \\
APD & Antero-Posterior Diameter; \\
dia & diaphysis; \\
dist & distal; \\
H & Height; \\
HI & Hypsodonty Index (H/L); \\
l & left; \\
L & Length; \\
m. & muscle; \\
Mc & metacarpal; \\
Mt & metatarsal; \\
post & posterior; \\
prox & proximal; \\
r & right; \\
TD & Transverse Diameter; \\
W & Width (when distinct from TD).
\end{tabular}

\section{Institutional abbreviations}

ITU Istanbul Technical University, Istanbul;

MNHN Muséum national d'Histoire naturelle, Paris. 
TABLE 1. - Rhinocerotidae from the upper Miocene locality of Küçükçekmece, European Turkey, dental measurements (in mm). Abbreviations: see Material and methods.

\begin{tabular}{|c|c|c|c|c|c|c|}
\hline Taxon & Specimen & No. & $\mathbf{L}$ & ant W & post W & $\mathbf{H}$ \\
\hline Ronzotherium sp. & I m1 or m2 & MNHN.F.TRQ355 & 54 & 32 & 35 & 27 \\
\hline Ceratotherium neumayri (Osborn, 1900) & r M1 & MNHN.F.TRQ343 & $>52$ & $>60$ & $>52$ & 8 \\
\hline Chilotherium schlosseri (Weber, 1905) & $\begin{array}{l}\text { r P2 } \\
\text { I P4 } \\
\text { r M2 } \\
\text { I M1-2 } \\
\text { I D3 } \\
\text { I D4 } \\
\text { r D4 } \\
\text { r i2 } \\
\text { r i2 } \\
\text { r i2 } \\
\text { I p3 } \\
\text { I p4 } \\
\text { I m1 } \\
\text { r m2 } \\
\text { r m3 } \\
\text { r p4 } \\
\text { I m2 } \\
r \text { m2 } \\
\text { I d3 }\end{array}$ & $\begin{array}{l}\text { MNHN.F.TRQ339 } \\
\text { MNHN.F.TRQ341 } \\
\text { KÇ297 } \\
\text { MNHN.F.TRQ344 } \\
\text { KÇ295 } \\
\text { MNHN.F.TRQ346 } \\
\text { KÇ305 } \\
\text { KÇ338 } \\
\text { MNHN.F.TRQ348 } \\
\text { MNHN.F.TRQ349 } \\
\text { MNHN.F.TRQ352 } \\
\text { MNHN.F.TRQ352 } \\
\text { MNHN.F.TRQ352 } \\
\text { MNHN.F.TRQ351 } \\
\text { MNHN.F.TRQ351 } \\
\text { MNHN.F.TRQ353 } \\
\text { MNHN.F.TRQ357 } \\
\text { MNHN.F.TRQ354 } \\
\text { MNHN.F.TRQ358 }\end{array}$ & $\begin{array}{l}29 \\
38 \\
40.5 \\
49 \\
41.5 \\
>42 \\
\quad- \\
(108) \\
(55) \\
(45) \\
- \\
37 \\
38 \\
40 \\
40 \\
37.5 \\
41.5 \\
42.5 \\
43 \\
\end{array}$ & $\begin{array}{l}31 \\
47 \\
53.5 \\
- \\
35.5 \\
- \\
- \\
- \\
- \\
- \\
- \\
23 \\
24.5 \\
24 \\
23 \\
22 \\
23.5 \\
22.5 \\
19 \\
\end{array}$ & $\begin{array}{l}32 \\
46 \\
- \\
- \\
- \\
36 \\
- \\
32 \\
24 \\
24 \\
25.5 \\
27 \\
26 \\
24 \\
21 \\
26 \\
24.5 \\
25 \\
22.5 \\
\end{array}$ & $\begin{array}{r}20 \\
56 \\
- \\
44 \\
- \\
>19 \\
- \\
25 \\
17 \\
16 \\
17 \\
18 \\
22 \\
25 \\
27 \\
26 \\
36 \\
51 \\
29 \\
\end{array}$ \\
\hline Persiatherium sp. & $\begin{array}{l}\text { r P2 } \\
\text { I P2 } \\
\text { I P3 } \\
\text { I P4 } \\
\text { I M1 } \\
\text { I M1 } \\
\text { I M1 } \\
\text { r i2 } \\
\text { I p2 } \\
\text { r p4 } \\
\text { I m1 } \\
\text { I m2 } \\
\text { I m3 } \\
\text { r d4 } \\
\text { r d4 }\end{array}$ & $\begin{array}{l}\text { KÇ300 } \\
\text { KÇ318 } \\
\text { KÇ318 } \\
\text { KÇ318 } \\
\text { KÇ318 } \\
\text { MNHN.F.TRQ340 } \\
\text { MNHN.F.TRQ342 } \\
\text { MNHN.F.TRQ347 } \\
\text { KÇ296 } \\
\text { KÇ301 } \\
\text { MNHN.F.TRQ356 } \\
\text { KÇ360 } \\
\text { KÇ360 } \\
\text { KÇ311 } \\
\text { MNHN.F.TRQ350 }\end{array}$ & $\begin{array}{l}35.5 \\
34 \\
37.5 \\
40.5 \\
40.5 \\
33.5 \\
41 \\
(110) \\
32.5 \\
42 \\
41 \\
41 \\
43.5 \\
38.5 \\
40\end{array}$ & $\begin{array}{l}42.5 \\
40 \\
48 \\
53 \\
50.5 \\
49 \\
47 \\
- \\
17 \\
18 \\
26 \\
27 \\
25.5 \\
25 \\
20\end{array}$ & $\begin{array}{l}- \\
42 \\
49 \\
46 \\
44 \\
49 \\
48.5 \\
28 \\
19.6 \\
20 \\
26 \\
27 \\
24.5 \\
26 \\
21.5\end{array}$ & $\begin{array}{l}- \\
- \\
- \\
- \\
- \\
10 \\
21 \\
24 \\
24 \\
24 \\
21 \\
16 \\
17 \\
21 \\
(28)\end{array}$ \\
\hline
\end{tabular}

\section{SYSTEMATICS}

Order PERISSODACTYLA Owen, 1848 Suborder TAPIROMORPHA Haeckel, 1866 Superfamily RHINOCEROTOIDEA Gray, 1821

Family RHINOCEROTIDAE Gray, 1821

Genus Ronzotherium Aymard, 1854

TYPE SPECIES. - Ronzotherium velaunum by original designation (Aymard 1854).

\section{Ronzotherium sp.}

(Fig. 1A-D)

MATERIAL. - MNHN.F.TRQ355, left m1-2.

\section{DESCRIPTION}

This large tooth is eroded, with a grey patina distinct from that of other studied specimens, and partly covered by recent marine organisms, such as serpulids, barnacles, and micromollusks. There is a wear facet due to a posterior tooth $(\mathrm{m} 2$ or $\mathrm{m} 3$; Fig. 1D), so it can be identified as an $\mathrm{m} 1$ or $\mathrm{m} 2$. The occlusal outline is rectangular (Fig. 1A). The crown is very low and bulbous with thick transverse lophids. The width/ length ratio is high (0.65). The paralophid is thin and low. Enamel is thinly crenulated and corrugated. The anterior cingulid is smooth but located high and horizontal. The labial cingulid is restricted to an oblique ridge at the bottom of the ectolophid groove (Fig. 1C). The anterior and posterior lingual valleys are closed by a crenulated ridge resembling a lingual cingulid (but not homologous with it). The posterior cingulid is continuous and sigmoid, with its lingual tip forming a spur pointed upward. Lingual cuspids are not constricted. The lingual side of the hypoconid is flat, vertical and straight. The talonid is very low with respect to the trigonid. The bottom of the posterior valley is rounded but $\mathrm{V}$-shaped (Fig. 1B) in lingual view.

\section{DisCUSSION}

As indicated by its grey patina and eroded aspect, this tooth is at odds with other tapiromorph remains from Küçükçekmece (quartz-rich red sands). Moreover, together with the large size of this tooth, most morphological features (rectangular 
outline, low and bulbous crown, high width/length ratio, shape and location of the cingulid, paralophid and hypolophid low, lophids transverse, lingual side of the hypoconid flat and straight) concur to point to the early diverging rhinocerotid Ronzotherium (Beliajeva 1954; Dashzeveg 1991; Antoine et al. 2003a; Ménouret \& Guérin 2009). Representatives of this genus are commonly occurring in late Eocene-Oligocene localities of Eurasia, and more specifically in Oligocene deposits of Europe (Brunet 1979; Uhlig 1999; Becker 2009; Ménouret \& Guérin 2009). Oligocene sedimentary deposits are mapped in the vicinity of Küçükçekmece West, and MNHN.F.TRQ355 likely originates from these levels. However, it is impossible to locate the exact provenance of this outlier specimen, as being a: i) reworked specimen amalgamated in upper Miocene sands or, more likely; and ii) a specimen recently extracted from Oligocene deposits by natural erosion, mixed up with upper Miocene deposits cropping out, and then surface-collected.

Subfamily RHINOCEROTINAE Gray, 1821

Tribe RHINOCEROTINI Gray, 1821

Genus Ceratotherium Gray, 1867

TYPE SPECIES. - Ceratotherium simum (Burchell, 1817) by original designation (Gray 1867: 1027).

\section{Ceratotherium neumayri (Osborn, 1900)} (Fig. 1E-M)

Rhinoceros pachygnathus - Malik \& Nafiz 1933: 45, 46.

Diceros aff. primaevus - Nicolas 1978: 456.

Diceros cf. neumayri - Nicolas 1978: 456.

MATERIAL EXAMINED. - MNHN.F.TRQ343, right M1 without ectoloph; TRQ360, right radius, proximal fragment; TRQ327, right Mc2; TRQ333, right calcaneus; TRQ334, right calcaneus, fragmentary and eroded.

\section{DESCRIPTION}

\section{Upper dentition}

The M1 MNHN.F.TRQ343 is worn, eroded, and largesized $(\mathrm{L}>52$; ant $\mathrm{W}>60$; post $\mathrm{W}>52$ ). The ectoloph is broken. Enamel is worn out. The occlusal pattern is simple, with a sigmoid protoloph devoid of constrictions, a simple sagittal crochet adjacent to the metaloph-ectoloph junction, and a short transverse metaloph (Fig. 1E). At this wear stage, the lingual valley, sigmoid in outline, is obturated lingually, due to connected but not fused protocone and hypocone. The protocone is much more developed than the hypocone. There is no lingual cingulum. Lingual roots are short and coalescent.

\section{Postcranial skeleton}

MNHN.F.TRQ360 is a proximal fragment of a right radius ( roxTD = 99; proxAPD = 59), badly preserved (with a corrugated aspect; Fig. 1F, G). In proximal view, the anterior border is concave (Fig. 1F). The lateral and the posterolateral borders connect through a right-angled ridge. The lateral humerus-facet is much less developed sagittally than its medial counterpart. In anterior view, these facets form a $140^{\circ}$ dihedron, pointing to a "diabolo-like" humeral trochlea. The proximal head is much wider than the diaphysis (Fig. $1 G)$. The insertion for the $m$. biceps brachii is delimitated by a rough surface, but without any fossa. In posterior view, the ulna-facets are badly preserved, being the medial one high and crescent-like.

The Mc2 MNHN.F.TRQ327 is quite slender ( $\mathrm{L}=147$; proxTD $=40 ;$ proxAPD $=42 ; \operatorname{diaDT}=38 ; \operatorname{diaAPD}=19$; $\operatorname{distTD}=38$; distAPD $=38.5$ ), with small proximal and distal articular heads (Fig. 1H). In proximal view, the bone has a triangular outline (Fig. 1I). The trapezoid-facet is convex sagittally and concave transversely, with a trapezoid outline. The magnum-facet is flat, sub-vertical and kidney-shaped. The Mc3-facets, badly preserved, were independent. There is no trapezium-facet. The diaphysis is sagittally compressed, slightly curved and concave medially in anterior view, with no distal widening. The distal end is as deep as wide (APD = TD) and wider posteriorly than anteriorly (strong antero-medial constriction). In distal view, the anterior border is slightly convex, the lateral border is straight and at a right angle with the former. The posterior border is W-shaped, with a medial lip deeply concave and a sharp keel restricted to the posterior half of the articulation (Fig. 1J).

The calcanei MNHN.F.TRQ333 (complete; Fig. 1K-M) and TRQ334 (fragmentary and eroded) have similar shape and dimensions and we therefore consider them as characterizing a single taxon. They are robust, with massive tuber calcanei $(T R Q 333: \mathrm{L}=119 ; \mathrm{TD}=67 ; \mathrm{APD}=66)$. There is no fibula-facet but a large almond-shaped tibia-facet (TRQ333; Fig. 1M). The astragalus-facet 1 has a falciform outline in lateral view, with no obvious postero-distal expansion. The facet 2 is subcircular (Fig. $1 \mathrm{~K}$ ) and nearly flat (subconcave). The facet 3 is smaller and almond-shaped. All three facets are independent one from another (Fig. 1K). The sustentaculum tali is thick (APD), but not so wide (TD) with respect to the dimensions of the bone (Table 1). The proximal tip of the tuber calcanei is as deep (APD) as the processus in lateral view (Fig. 1M). The posterior border of the calcaneus is straight in lateral view. The cuboid-facet, on the distal side, is saddle-shaped, with a kidney-like outline (Fig. 1K). The insertion for the $m$. fibularis longus forms a smooth tubercle sagittally elongated.

\section{DisCUSSION}

Dental and postcranial remains from Küçükçekmece West closely resemble those of $C$. neumayri from the late Miocene of eastern Mediterranean, in terms of shape. Their dimensions, perfectly matching those originating from Vallesian localities (e.g., Karacaşar, MN10; Antoine et al. 2012), are 10 to 25\% smaller and somewhat slenderer than those of specimens from Turolian localities, such as Akkaşdağı, Samos, or Pikermi (Geraads 1988, 1994; Kaya \& Heissig 2001; Antoine \& Saraç 2005). Moreover, the presence of a strong lateral tuberosity 


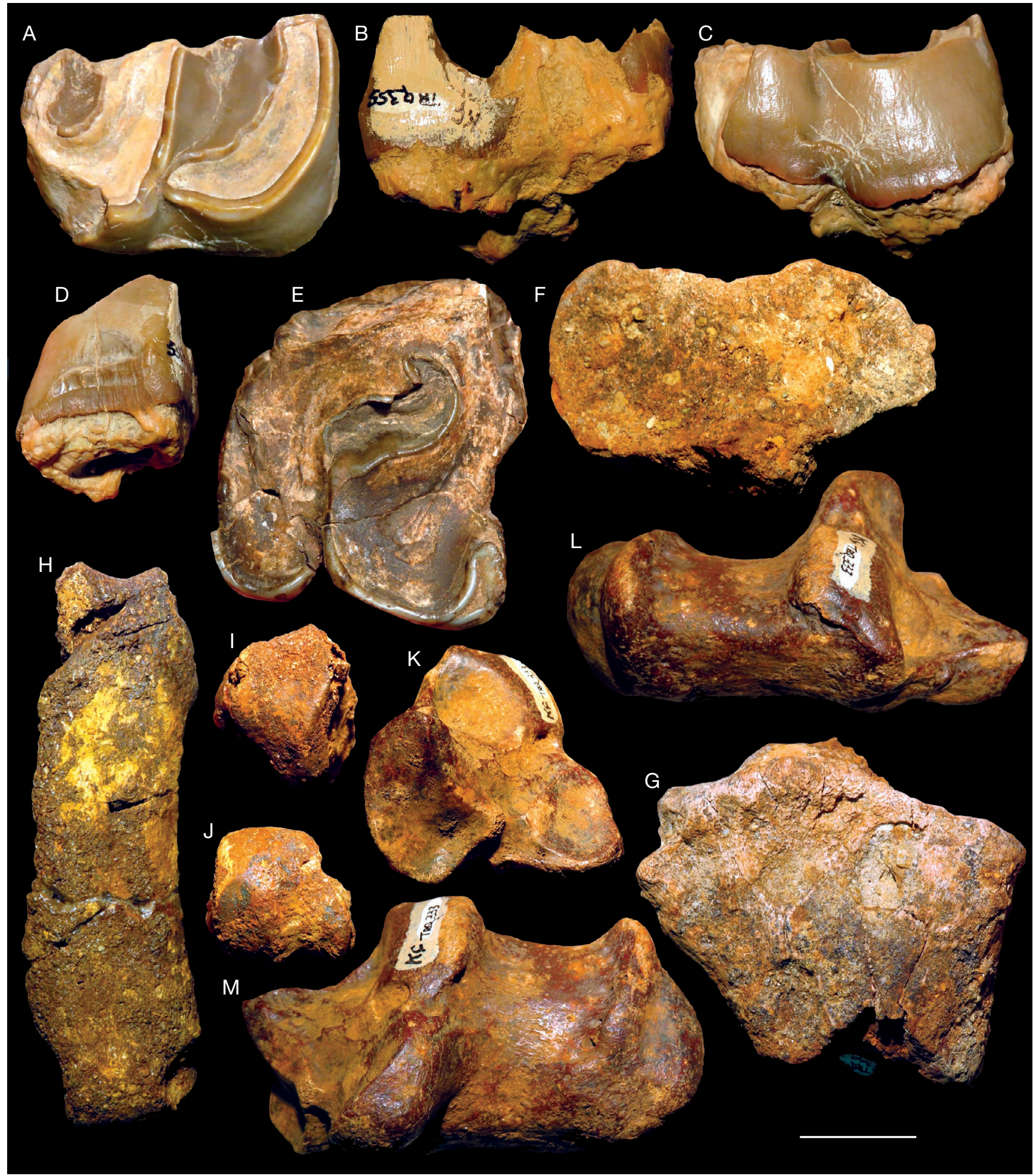

FIG. 1. - Tapiromorph perissodactyls from the upper Miocene locality of Küçükçekmece, Thrace, Turkey: A-D, Ronzotherium sp. (reworked); MNHN.F.TRQ355, left $\mathrm{m} 1$ or $\mathrm{m} 2$ in occlusal (A), lingual (B), labial (C), and posterior views (D); E-M, Ceratotherium neumayri; E, TRQ343, right M1 in occlusal view; F-G, TRQ360, right radius in proximal $(\mathbf{F})$ and anterior views $(\mathbf{G})$; H-J, TRQ327, right Mc2, in anterior (H), proximal (I), and distal views (J); K-M, TRQ333, right calcaneus, in dista $(\mathbf{K})$, anteroproximal (L), and medial views (M). Scale bar: A-E, $20 \mathrm{~mm}$; F-M, $30 \mathrm{~mm}$.

on the radius, the absence of a trapezium-facet and of a longitudinal crest on the posterior surface of the diaphysis on the Mc2, and the low development of the tuber calcanei on the calcaneus discard any referral of the concerned specimens to Dihoplus pikermiensis (Toula, 1906), another conspicuous two-horned rhinocerotine from the late Miocene of eastern Mediterranean (Geraads 1988; Giaourtsakis 2009; L. Pandolfi pers. comm. 04/2016) 
Tribe ACERATHERIINI Dollo, 1885

Genus Chilotherium Ringström, 1924

TYPE SPECIES. - Chilotherium anderssoni Ringström, 1924, by original designation.

\section{Chilotherium schlosseri (Weber, 1905)}

(Fig. 2)

Chilotherium kowalevskii - Pavlow 1913: 48-67. pl. 4-5.

Aceratherium sp. - Malik \& Nafiz 1933: 44-45, pl. VII, figs. 4-5.

Aceratherium cf. kowaleskii [partim] - Nicolas 1978: 456.

MATERIAL EXAMINED. - MNHN.F.TRQ339, right P2; TRQ341, left unworn P4; KÇ297, right M2; TRQ344, ectoloph of a left M12; KÇ295, left D3; TRQ346, left D4 (without ectoloph); KÇ305, right D4 (broken); KÇ338, right i2; TRQ348, right i2 (anterior tip); TRQ349, right i2 (anterior tip); TRQ352, left mandible fragment with p3 (talonid)-m1; TRQ351, right mandible fragment with m2-3; TRQ353, right p4 (germ); TRQ357, left m2; TRQ354, right m2; TRQ358, left d3; TRQ330, right Mc3 (without distal end); TRQ329, right Mc4; TRQ364, left cuboid; TRQ335, left Mt3 (proximal fragment).

\section{DESCRIPTION}

\section{Upper dentition}

The upper teeth referable to this taxon are high-crowned (Table 1), with thinly wrinkled enamel and scattered patches of cement on the ectoloph. The dental pattern is more complicated than in the other aceratheriine from Küçükçekmece (Fig. 3), notably due to the presence of secondary folding and accessory enamel tubercles (Fig. 2A, B, E-G). Apart from P2 (ectoloph convex, without any fold; Fig. 2A), all other upper teeth have undulated ectolophs in occlusal view, with a parastyle and a long metastyle pointing labially, a shallow parastyle groove and a smooth paracone fold on P4 and M1-2 (deep/thick on D3), but also a smooth mesostyle on molars and D3 (Fig. 2F). On upper teeth (premolars, molars, and upper deciduous teeth), the lingual cingulum is low and reduced, restricted to the median part of the lingual wall, whereas the labial cingulum is restricted to enamel tubercles running along the anterior and posterior edges of the ectoloph (e.g., Fig. 2D). The postfossette is narrow transversely and elongate sagittally, especially after early wear stages (Fig. 2E). The morphology of roots is essentially unknown. On upper premolars, the metaloph forms a dihedron, with a thick sagittal crochet located at the anterior angle, either right-angled (P2 MNHN.F.TRQ339) or open-angled (P4 TRQ341). The P2 TRQ339 is small and with a trapezoid occlusal outline (lingually compressed; Fig. 2A). The parastyle is as thick as the metastyle. The prefossette is wide and deep, bordered lingually by a sharp groove, coinciding with the protocone constriction. The protoloph is complete. The protocone is partly broken. There is neither antecrochet nor crista. The metacone and the hypocone are located at the same level in occlusal view. The protocone and the hypocone, equally developed, are strongly connected by a thick lingual bridge. Accordingly, the median valley is closed and $\mathrm{V}$-shaped in occlusal view. The P4 MNHN.F.TRQ341 is unworn (Fig. 2B-D), which allows for determining the hypsodonty index $(\mathrm{H} / \mathrm{L}=1.19)$. The ectoloph is very high, but convex and oblique, as is the lingual border, in sagittal view. As a consequence, the occlusal surface is much narrower at early wear stages than at late wear stages. At the same time, the ectoloph is shortening sagittally with wear, which leads to a drastic change in terms of W/L ratio during the lifetime of the individual. The crochet is simple, long and sharp, and sagittally oriented. The antecrochet is strong, sharp and developed at any wear stage. The protoloph is curved (convex anteriorly) and completely connected to the ectoloph. There is a shallow protocone constriction, restricted to the base of the crown. The protocone and the hypocone are distant and not connected (molariform pattern). There is neither crista nor medifossette. The metaloph is thin but lacking a constriction. It is very short with respect to the protoloph and pointing postero-lingually, in occlusal view. The posterior cingulum is very low and $\mathrm{V}$-shaped in posterior view. KÇ297 is a right M2, damaged in its lingual and posterolabial parts (Fig. 2E). The antecrochet is strongly developed, sharp, and located labially with respect to the deep protocone constriction. The protoloph is sigmoid in occlusal view. The crochet is thick but short, closely appressed to the ectoloph and neighboring a small enamel fold (crista?). There is neither medifossette nor cristella. The median valley is sigmoid, narrow, and open lingually. The lingual cingulum is not preserved, but there is a small enamel tubercle at the bottom of the median valley. The metaloph is short with respect to the protoloph in occlusal view. The posterior cingulum is low but continuous, following the $\mathrm{V}$-shaped pattern of the bottom of the postfossette. There is a deep hypocone constriction, restricted to the base of the crown. The antecrochet does not connect the metaloph, even at late wear stages.

The upper deciduous teeth are molariform, with patterns similar to those of permanent teeth (ectoloph undulated, with strong paracone and metacone folds and a smooth mesostyle; anterior cingulum strong and complete; protoloph curved; crochet long, sharp, and sagittal; protocone and hypocone constricted; antecrochet long and sharp, connecting the metaloph in late wear stages; lingual cingulum reduced; postfossette deep, narrow, and triangular in occlusal view; metastyle very long). Yet, they are more brachydont, with thinner enamel, and a lighter patina. The left D3 KÇ295 is complete, with a very long parastyle and a sharp crista, but no medifossette (Fig. $2 \mathrm{~F}$ ). The parastyle groove is much deeper than in permanent teeth (not preserved on D4s). Its median valley is open until late wear stages (no lingual wall), but much wider in occlusal view than in D4 (MNHN.F.TRQ346 and KÇ305). There is no crista on $\mathrm{D} 4 \mathrm{~s}$. The lingual roots are connected but unfused on TRQ346 (Fig. 2G).

\section{Mandible and lower dentition}

The $\mathrm{i} 2 \mathrm{KÇ338}$ is cracked (long emersion) and eroded (e.g., transported). Most enamel has disappeared with wear and 


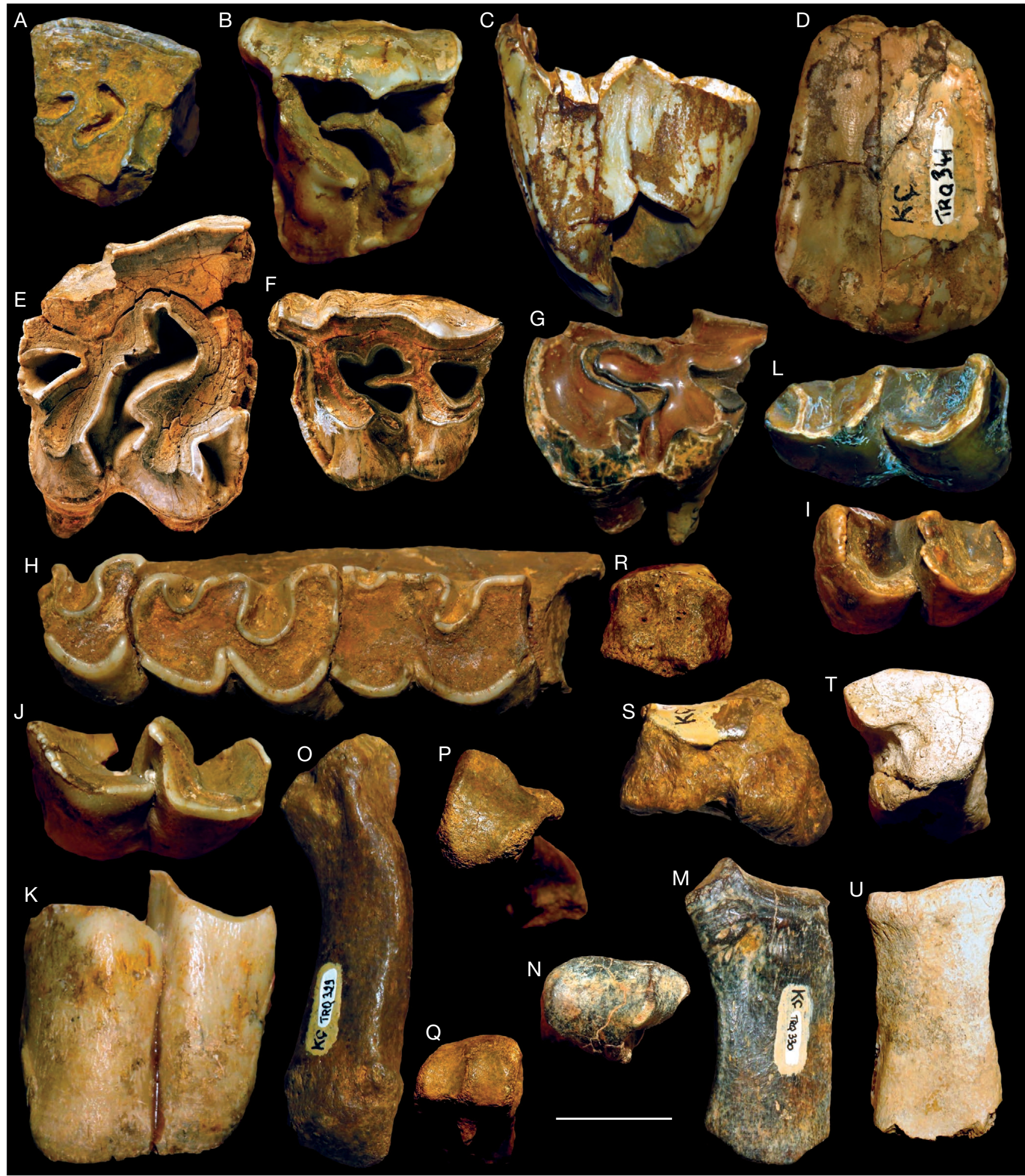

FIG. 2. - Tapiromorph perissodactyls from the upper Miocene locality of Küçükçekmece, Thrace, Turkey. Chilotherium schlosseri (Weber, 1905): A, MNHN.F.TRQ339, right P2 in occlusal view; B-D, TRQ341, left unworn P4 in occlusal (B), posterior (C), and labial views (D); E, KCC297, right M2 in occlusal view; F, KC295, left D3 in occlusal view; G, TRQ346, left D4 in occlusal view; H, TRQ352, left mandible fragment with p3-m1 in occlusal view; I, TRQ353, right p4 (germ) in occlusal view; J-K, TRQ354, right $\mathrm{m} 2$ in occlusal (J) and labial views (K); L, TRQ358, left d3 in occlusal view; $\mathbf{M}, \mathbf{N}$, TRQ330, right Mc3 without distal end, in anterior (M) and proximal views (N): O-Q TRQ329, right Mc4 in anterior $(\mathbf{O})$, proximal $(\mathbf{P})$, and distal $(\mathbf{Q})$ views, note the presence of a posterodistal tubercle on the diaphysis $(\mathbf{Q}) \cdot \mathbf{R}, \mathbf{S}$, TRQ364, left cuboid in anterior (R) and lateral views (S); T, U, TRQ335, left Mt3 (proximal fragment) in proximal (T) and anterior views (U). Scale bar: A-L, $20 \mathrm{~mm}$; M-U, $30 \mathrm{~mm}$.

the neck is not easily discernable. It has a straight and cylindrical root, and the tip of the crown is curved, in a similar way to MNHN.F.TRQ348 and TRQ349 (crowns preserved, root broken). The cross section of the crown is a right triangle. The wear facet is flat transversely and concave sagittally. 
The mandibular fragments are badly broken and they yield no morphological feature.

Lower teeth are high-crowned (p4 MNHN.F.TRQ353: HI = 1.17; m2 TRQ354: HI = 1.2). There is no lingual or labial cingulid, but a short anterolingual ridge borders the paralophid on TRQ351 (m2-m3). The ectolophid groove, deep and $\mathrm{V}$-shaped in occlusal view, reaches the neck and points up- and frontward in labial view. There is no cement preserved. Lingual cusps are constricted on most fresh teeth: metaconid of p4 (TRQ353), m2 (TRQ357), and m3 (TRQ351); entoconid of $\mathrm{m} 2$ (TRQ351 and TRQ357), and m3 (TRQ351). The trigonid is smooth and right-angled, and U-shaped in occlusal view. The lingual valleys are narrow and $\mathrm{V}$-shaped in lingual view. Lophids are oriented transversely on premolars (Fig. 2H, I). Premolars have wide hypolophids with respect to trigonids. On m2-m3, the hypolophid is very oblique, especially at early wear stages (Fig. 2J). There is no lingual groove on the entoconid. The p3 TRQ352 lacks any external rugosity. The lingual border of the lingual cusps is flattened. The posterior cingulum is low and particularly smooth on m2-m3 (TRQ351, TRQ354, and TRQ357).

The left d3 MNHN.F.TRQ358 is elongate sagittally (Fig. $2 \mathrm{~L}$ ), and quite high-crowned for a deciduous tooth (Table 1). The paralophid is forked, with a sharp sagittal spur. There is an incipient groove on the labial side of the trigonid. The labial cingulid is restricted to a short and low ridge closing the shallow ectolophid groove. There is no lingual cingulid (Fig. $2 \mathrm{~L}$ ). The lingual cusps are not constricted and there is no protoconid fold. The lingual valleys are $\mathrm{V}$-shaped in lingual view.

\section{Postcranial skeleton}

All available metapodials have wide and sagittally-flattened diaphyses and long insertions for the $m$. interossei. Metacarpals have strong and thick insertions for the $m$. extensor carpalis, contrary to the Mt3 TRQ335 (flat surface) referred to as Persiatherium sp. (Fig. 3L, M). The Mc3 TRQ330 lacks its distal end (Fig. 2M). In proximal view, it is much wider $(\mathrm{TD}=$ 47) than deep $(\mathrm{APD}=35)$, with a rounded aspect $($ Fig. $2 \mathrm{~N})$. There seems to be no scaphoid-facet. The semilunate-facet is quadrate in proximal view, concave transversely, and elongated and convex sagittally. The unciform-facet is flat transversely and strongly convex sagittally, separate from the former by a smooth ridge $\left(c .110^{\circ}\right)$. The strong tubercle for the insertion of the $m$. extensor carpalis determines a deep groove proximal to it. In anterior view, the magnum-facet is visible. There is only one Mc2-facet, restricted to a low almond-shaped strip, elongate sagittally. The Mc4-facets are oval and distant one from another. The anterior one is located much more proximally. The medial border of the diaphysis is straight whereas the lateral border is strongly and regularly concave.

TRQ329 is a complete Mc4, with an eroded surface (Fig. $2 \mathrm{O}-\mathrm{Q})$. Its proximal and distal ends are not widened with respect to the diaphysis $(\mathrm{L}=112$; prox $T D=29$; $\operatorname{proxAPD}=$ 29 ; $\operatorname{diaDT}=25 ;$ diaAPD $=13.5$; $\operatorname{distTD}=28 ;$ distAPD $=$ 30). The diaphysis is strongly curved in its proximal third (concave laterally; Fig. 2O), which fits the shape of the Mc3 MNHN.F.TRQ330 (Fig. 2M). The proximal facet has a pen- tagonal outline, due to the Mc3-facets forming a $135^{\circ}$ angle in proximal view. The Mc5-facet has no delimited outline: it coincides with the smooth and rounded lateral border of the proximal end. There is a thick tubercle at the antero-lateral angle of the bone, corresponding to the insertion for the $m$. extensor carpalis (Fig. 2P). In medial view, the Mc3-facets are disconnected and subvertical. The anterior facet is flat and elongate sagittally, whereas the posterior one is oval and elongate proximo-distally. In medial view, the diaphysis is straight, with a salient posterodistal tubercle on the median part of the diaphysis (Fig. 3Q), just proximal to the distal articulation. In distal view, the distal pulley has a quarter-circle outline, as wide as deep (TD = APD), and with a postero-medial right angle. The intermediate relief is sharp, separating two concave lips equally developed transversely.

The left cuboid MNHN.F.TRQ364 is robust and low anteriorly $(\mathrm{H}=40 ; \mathrm{TD}=33.5 ; \mathrm{APD}=54.5$; ant $\mathrm{H}=26.5)$, with salient muscular insertions (Fig. 2R, S). In proximal view, the proximal facet is heart-shaped (triangular, with an anterior inflection) and saddle-shaped. It is split into two equal parts by a shallow sagittal groove; the astragalus-facet is more developed sagittally than the calcaneus-facet. In anterior view, the anterior side has a convex proximal border, parallel medial and lateral sides, and a posterior border forming an open dihedron (c. $135^{\circ}$; Fig. 2R). On the medial side, the antero-proximal facet is damaged. The postero-proximal facet (for the ectocuneiform) has a cochlear shape. It is much larger than the antero-distal facet, semi-oval and elongate proximodistally. The posterior tuberosity is well developed, with an oblique posterior border in lateral view (Fig. 2S). The distal tip of such tuberosity well overhangs the distal articulation. It is longer medially than laterally. The distal MtIV-facet is T-shaped in distal view, as deep as wide (APD = TD). It is slightly concave sagittally and strongly convex transversely.

MNHN.F.TRQ335 is a proximal fragment of a left Mt3 (Fig. 2T, U). In anterior view, the proximal border is sigmoid (Fig. 2U). The diaphysis was probably widened distally. In proximal view, the proximal end is almost as deep $(\mathrm{APD}=36.5)$ as wide ( $T D=38.5)$, due to posteriorly-projected posterior Mt3-facet (Fig. 2T); the ectocuneiform-facet is L-shaped, with an anterior border forming a widely open dihedron $\left(c .160^{\circ}\right)$; there is no cuboid-facet. The medial surface is much eroded, which impedes any observation on $\mathrm{Mt} 2$-facet(s). In lateral view, the Mt4-facets are large and remote. The anterior one is vertical, with a semi-circular outline. It connects the proximal facet. The posterior facet is subvertical (visible in proximal view), and projected posteriorly. The diaphysis is flattened, but much more pinched laterally than medially.

\section{DISCUSSION}

The smallest rhinocerotid from Küçükçekmece is undoubtedly referable to Aceratheriina (sensu Antoine et al. 2003b, 2010) or Aceratheriini (sensu Lu 2013; Pandolfi 2016), due to the presence of wrinkled enamel on cheek teeth, of upturned i2s, of protocone and hypocone equally developed on P2, of a metaloph constriction on P2-4, of a weak paracone fold on M1-2, and of a constricted hypocone on M2. Morphological 
features, such as partial hypsodonty, the presence of a protocone constriction on P3-4 and a strong antecrochet on upper molars, of a deep ectolophid groove reaching the neck on lower cheek teeth, or the absence of labial cingulum on lower cheekteeth, allow for recognizing it as a "chilothere" sensu lato (i.e. an unformal cluster of aceratheriines including Chilotherium Ringström, 1924, Acerorhinus Kretzoi, 1942, Shansirhinus Kretzoi, 1942, and Persiatherium Pandolfi, 2016). Among chilotheres, it can be identified as belonging to Chilotherium based on the presence of a reduced lingual cingulum on upper premolars, of protocone and hypocone separate at early wear stages and later connected by a lingual bridge on P2, of a strong antecrochet on $\mathrm{P} 4$, of a labial cingulum restricted to the anterior and posterior edges of the ectoloph on upper molars, of a strong protocone constriction on upper molars, and the absence of a metaconid constriction on lower milk teeth. The available remains share the closest affinities with Chilotherium schlosseri (Weber, 1905), from the late Vallesian of Ukraine (upper MN9 and MN10; see Vangengeim \& Tesakov 2013) and its coeval Chilotherium kowalevskii (Pavlow, 1913) from Moldova and Ukraine (MN10; Vangengeim \& Tesakov 2013). C. kowalevskii is considered here as a junior synonym of Chilotherium schlosseri. Both have strikingly similar craniodental features and concurring ranges (early late Miocene), north to the Black Sea in Ukraine and Moldova. Although not explicitly stated, this synonymy was already suggested by the results of the phylogenetic analysis of aceratheriines as proposed by Pandolfi (2016). Interestingly, Nicolas (1978) had assigned the chilothere remains from Küçükçekmece West to "Aceratherium cf. kowalevskii".

The small chilothere from Küçükçekmece shares salient dental features with $C$. schlosseri, such as the presence of a lingually-projected antecrochet and of a continuous posterior cingulum on upper molars, of a deep and V-shaped ectolophid groove on lower cheekteeth, and of a strong mesostyle on D3. It further differs from other Chilotherium species in having no median incision of the lingual cingulum on upper premolars, no antecrochet on $\mathrm{P} 2$, protocone and hypocone equally developed on P2, lingual cusps separate on P3-P4, and a double paralophid on d3 (see comparison in Lu 2013 and Pandolf 2016). The lingual border of the lingual cusps is flattened (contrary to what is observed on teeth from Küçükçekmece referred to as Persiatherium sp.).

\section{Genus Persiatherium Pandolfi, 2016}

TYPE SPECIES. - Persiatherium rodleri Pandolfi, 2016 by original designation (Pandolfi 2016: 2).

\section{Persiatherium sp.}

(Fig. 3)

Aceratherium sp. [partim] - Malik \& Nafiz 1933: 44.

Aceratherium sp. - Sayar 1953: 9, fig. 2.

Aceratherium cf. kowaleskii [partim] - Nicolas 1978: 456.
Material eXamined. - KÇ300, right P2; KÇ318, left P2-M1 series; MNHN.F.TRQ340, left M1; TRQ342, left M1; TRQ347, right i2; KÇ296, left p2 (germ); KÇ301, right p4; TRQ356, left m1; KÇ360, partial left hemimandible with m2-m3; KÇ311, right d4; TRQ350, right dentary fragment with d4; TRQ365, left pyramidal; TRQ328, right Mc3, proximal fragment.

\section{DESCRIPTION \\ Upper dentition}

The presence of $\mathrm{I} 1$ is inferred by the existence of a large and flat wear facet on i2 (MNHN.F.TRQ347). There is no secondary enamel folding on P2-M1, but pinched lingual cusps in occlusal view. Patches of cement are preserved on the ectoloph (Fig. 3A). Crowns are worn and enamel is finely wrinkled. Morphology of roots is unknown. The lingual rim of the upper row KÇ318 is straight (Fig. 3A). The labial cingulum is low and reduced, restricted to the distalmost part of all teeth (P2-M1). The lingual cingulum is thick and continuous on P2-M1, with salient tubercles closing the median valley. Premolars from the P2-M1 series KÇ318 are large with respect to $\mathrm{M} 1$, highly molarized, and wider than long in occlusal view (Table 1). The prefossette is shallow on P2. A simple crochet is present on P2 (low on KÇ300; Fig. 3B) and P4 (KÇ318). It has disappeared with wear on P3 and M1 (KÇ318) but also on the M1s TRQ340 and TRQ342. The postfossette is deep and narrow, elongate mesio-distally on P2-M1 (Fig. 3A). There is no antecrochet on P2, but a rounded one is discernable on $\mathrm{P} 3-\mathrm{P} 4$, and M1 has a far more marked antecrochet. A mesial wear-facet testifies to the presence of a P1 in front of P2s. P3 has a pentagonal occlusal outline (KÇ300, KÇ318), due to its convex lingual border. P2 has a protocone unconstricted mesially, while a shallow and smooth constriction is observed on P3-M1. There is a low and thin lingual bridge on $\mathrm{P} 2$, with equally developed hypocone and protocone (Fig. 3A, B). The metastyle is particularly elongate sagittally on P2-M1. The protoloph is complete on P2, but its labial connection to the ectoloph was low, as testified by the enamel pad preserved on KÇ300 (Fig. 3B). On P2, the protoloph is oblique (protocone located behind the paracone) whereas the metaloph is more transversely oriented, at least at early stages of wear (KÇ300). The protoloph is straight on P2 and curved disto-lingually on P3-M1. The protoloph is complete on P2-4. The metaloph is sigmoid, but unconstricted on P2-M1 (no mesiolabial constriction at the base of the hypocone). The postfossette is triangular on fresh teeth (P2 KÇ300) and getting narrower with wear (lingual side oblique: P2-M1 KÇ318). The labial cingulum is restricted to oblique ridges in the anterior and posterior quarters of the ectoloph. The median valley is extremely narrow, with parallel borders, on P2-M1. No medifossette is preserved on P2-M1, at least at advanced stages of wear. Nevertheless, the presence of joined crista and crochet (thus forming a medifossette at early wear stages) can be hypothesized on P3. There is no pseudometaloph on P3. The parastyle is sagittally oriented and the paracone fold weak (P4-M1, P2 KÇ300) or absent (worn P2-3). There is neither mesostyle nor metacone fold on P2-M1. In occlusal view, the ectoloph is thick, forming a labial wall, convex on P2 and straight or concave posteriorly 
on P3-M1. The metaloph is very short with respect to the protoloph on P4, whereas they have similar lengths on P3 and M1. There is no cristella on M1. The distal cingulum is continuous on P2-M1. The antecrochet and the hypocone are close to each other but not in contact or connected on $\mathrm{M} 1$, even at late wear stages. There is no lingual groove on the protocone of P2-M1.

\section{Mandible and lower dentition}

The mandible with m2-3 (KÇ360) is only partly preserved (Fig. 3C, D). The ramus was low, with a straight lower margin and a height increasing regularly backward $(\mathrm{H}=81$ under $\mathrm{m} 2$; $\mathrm{H}=88$ under $\mathrm{m} 3$; Fig. 3C). There is a long spatium retromolare, equal to the length of $\mathrm{m} 3$. The juvenile mandible fragment with $\mathrm{d} 4$ (MNHN.F.TRQ350) is much lower $(\mathrm{H}=58$ below the $\mathrm{d} 4-\mathrm{m} 1$ transition). There is a shallow sulcus mylohyoideus restricted to the posterior part of the preserved area. Other mandibular features are not observable.

The i2 MNHN.F.TRQ347 is cylindrical and slightly curved. The crown is short and tear-shaped in cross section. The root is circular in cross section. The wear facet is wide and flat, unambiguously corresponding to occlusion with an I1.

Enamel is thinly wrinkled on lower teeth, sometimes showing superimposed horizontal increments (p2 KÇ296; "squared enamel" sensu Antoine et al. 2010: 152; Fig. 3F) and patches of cement in inner valleys (e.g., p4 MNHN.F.TRQ353; Fig. 3G, $\mathrm{H})$. The left $\mathrm{p} 2$ is totally unworn (germ), with an angular trigonid and a rounded talonid (Fig. 3E). The paralophid is straight and oblique (neither sagittal nor transverse), with no constriction. The paraconid is strongly developed. There is no vertical external rugosity. The external groove is developed, sharp, and reaching the neck. The lingual cingulum is low and reduced, restricted to the anterior tip of the tooth and to oblique ridges at the lingual side of the metaconid and the entoconid. These cusps are not constricted, but a small ridge is visible at the top of the entoconid (corresponding to a "pre-entocristid"). The anterior valley is shallow, with a subvertical bottom. The posterior valley is deep and narrow, with a V-shaped bottom in lingual view. There is no labial cingulid. The right $\mathrm{p} 4$ KÇ301 has a simple pattern, with a deep and V-shaped ectolophid groove (Fig. 3G). Enamel is thick. There is neither lingual nor labial cingulid. Lingual cusps are not constricted. The trigonid is smooth and rightangled. Lophids are oriented transversely. Lingual valleys have a V-shaped bottom, widely open lingually (Fig. $3 \mathrm{H}$ ).

The $\mathrm{m} 1 \mathrm{MNHN}$.F.TRQ356 is small and brachydont, with a bulbous aspect (Fig. 3I; Table 1). In occlusal view, the trigonid forms a closed angle, with a sharp ridge. The talonid is smooth and open-angled (hypolophid oblique). There is neither constriction on the metaconid nor on the entoconid. The labial cingulum is low but complete, parallel to the neck. The ectolophid groove is shallow, V-shaped, pointing up- and frontward, and partly covered by patches of cement. Both lingual valleys have smoothed V-shaped bottoms. The lingual border of the lingual cusps is not flattened. There is no lingual cingulum. The posterior cingulum is low and smooth.
On the fragmentary mandible KÇ360, roots are exposed, especially on the labial side molar. Therefore molar necks are located c. $10 \mathrm{~mm}$ above the mandibular margin. The ectolophid groove is moderately deep on $\mathrm{m} 2-\mathrm{m} 3$, pointing up- and frontward in labial view, and it reaches the neck. The trigonid is rounded and it forms an open angle. The lingual cusps are not constricted. The anterior valley (U-shaped bottom) is really shallow with respect to the talonid valley (V-shaped bottom). There is no labial cingulid, but a reduced lingual cingulid, closing the entrance of both valleys in $\mathrm{m} 2-3$. The hypolophid of m2-3 is moderately oblique in occlusal view. There is no lingual groove on the entoconid.

The d4s KÇ311 (moderately worn; Fig. 3J) and MNHN.F.TRQ350 (germ) are highly similar in terms of size and morphology. They are brachydont, with a simple pattern. The trigonid and the hypolophid form a rounded U (paralophid long and transverse) and an open angle (hypolophid oblique) in occlusal view, respectively. The protoconid is the higher cusp. It lacks a fold. The metaconid is constricted, contrary to the entoconid (Fig. 3J). The latter has a flat and vertical lingual side, without any groove. The lingual valleys have a rounded V-shaped bottom in lingual view. There is neither lingual nor labial cingulum. The ectolophid groove is shallow and not reaching the neck.

\section{Postcranial skeleton}

The left pyramidal MNHN.F.TRQ365 is almost isometric $(\mathrm{H}=49 ; \mathrm{TD}=37.5 ; \mathrm{APD}=47)$. In proximal view, it has a quarter-circle outline, with a semi-circular ulna-facet. The pisiform-facet is tear-shaped in proximal view. There is no strong tubercle on the lateral side (contrary to what occurs in Ceratotherium neumayri). The medial facets for the semilunate are low and remote (Fig. 3K). The proximal one forms a low sagittally elongated strip. The distal one is crescent-like, slightly higher posteriorly. In distal view, the unciform-facet has a circular outline. It is flat transversally and concave sagittally.

MNHN.F.TRQ328 is a proximal fragment of a right Mc3 (Fig. 3L, M). In proximal view, it is wider $(\mathrm{TD}=44)$ than deep (APD $=37)$. The scaphoid-facet is small and oblique (Fig. 3M). The semilunate-facet is pear-shaped, concave transversely, but elongate and convex sagittally. The unciform-facet is flat transversely and separate from the former by a sharp ridge $\left(c .90^{\circ}\right)$. A strong tubercle for the insertion of the $m$. extensor carpalis runs along the proximal border or the anterior side. In anterior view, the magnum-facet is visible (Fig. 3L). There is only one Mc2-facet, restricted to a low tear-shaped strip, located anteriorly. The Mc4-facets are remote, with similar heights. The anterior one is high, narrow, and tear-shaped. The posterior one is oval, higher than wide. The diaphysis was wide and flattened sagittally. This bone is globally similar to TRQ330 (referred to Chilotherium schlosseri), but it differs from it in several features (angle between proximal facets in anterior view; shape of unciform-facet; proportions of proximal outline). It also resembles the specimen AS.91.229 from the late Miocene of Sinap area (locality 26, c. 8 My-old), tentatively referred to as Acerorhinus sp. by Fortelius et al. (2003). 


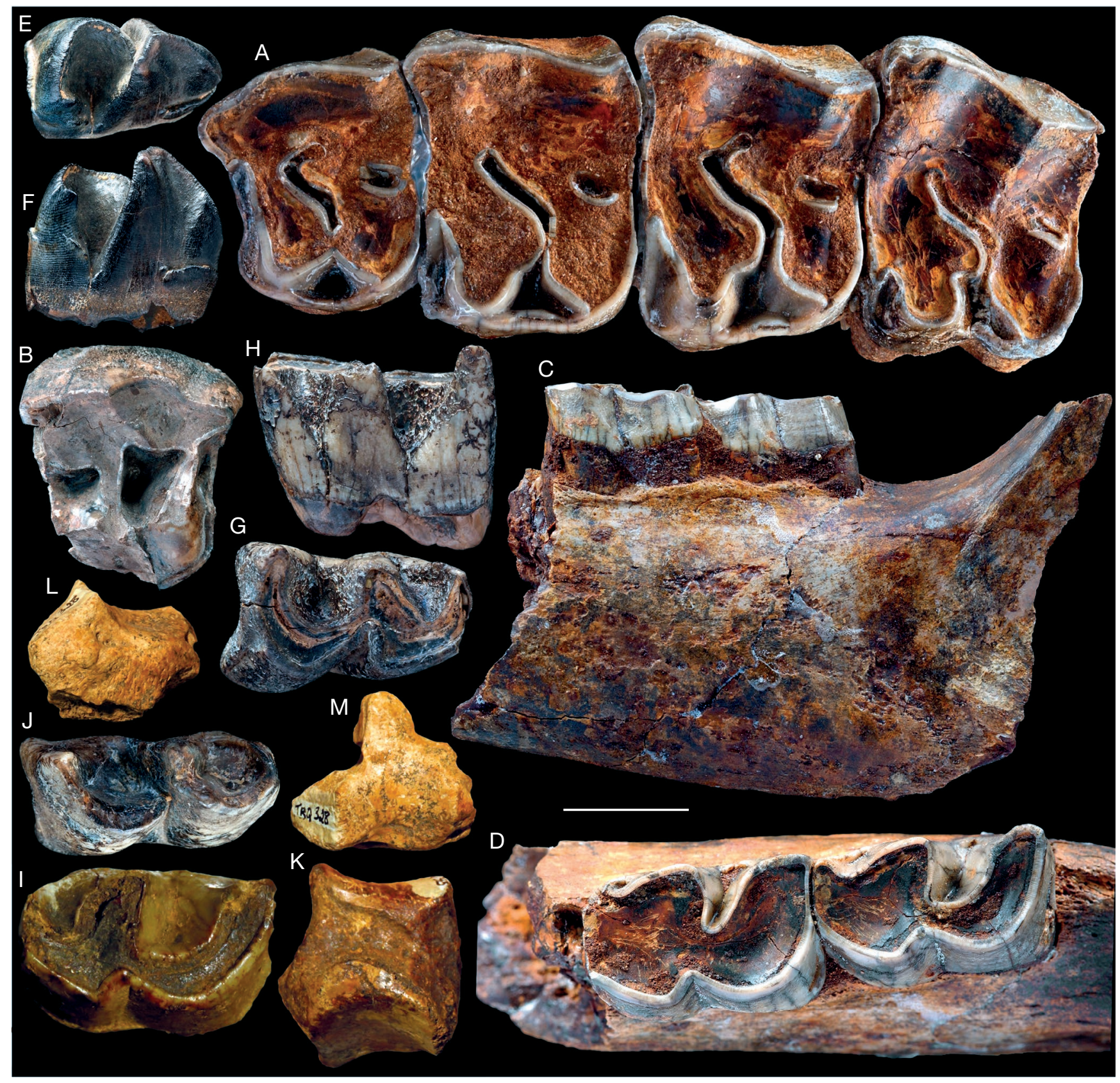

FIG. 3. - Tapiromorph perissodactyls from the upper Miocene locality of Küçükçekmece, Thrace, Turkey, Persiatherium sp.: A, KÇ318, left P2-M1 series in occlusal view; B, KCC300, right P2 in occlusal view; C, D, KCC360, left dentary with m2-m3 in labial (C) and occlusal views (D); E, F, KCC296, left p2 (germ) in occlusal (E) and lingual views (F); G, H, KÇ301, right p4 in occlusal (G) and lingual views (H); I, MNHN.F.TRQ356, left m1 in occlusal view; J, KÇ311, right d4 in occlusal view; K, TRQ365, left pyramidal in medial view; L, M, TRQ328, right Mc3 (proximal fragment) in anterior (L) and proximal views (M). Scale bar: A, B, $20 \mathrm{~mm}$; C, K-M, 30 mm.

\section{DisCUSSION}

The concerned remains can be referred to as documenting an aceratheriine rhinocerotid, thanks to the presence of wrinkled enamel on cheek teeth, of equally developed protocone and hypocone on P2, of a continuous protoloph (connected to the ectoloph) on $\mathrm{P} 2$, of a weak protocone fold on M1-2, to the usual absence of a labial cingulid on lower molars, and of a protoconid fold on d4. It is further recognizable as a "chilothere" sensu lato, in sharing a constricted protocone on P3-4, a crista on P3, an antecrochet on upper molars, an ectolophid groove reaching the neck, a U-shaped occlusal outline of the trigonid on lower cheekteeth, and a curved paralophid on p2, but also in having no labial cingulum on upper molars or on lower premolars, and no crista on upper molars. This early diverging chilothere is differentiated from representatives of Shansirhinus, Acerorhinus, and Chilotherium (including the other chilothere recognized at Küçükçekmece, Chilotherium schlosseri) in retaining $\mathrm{I} 1 \mathrm{~s}$, in having a continuous lingual cingulum on upper premolars but neither labial cingulum nor lingually expanded antecrochet on upper molars, in bearing a weaker protocone constriction on M1-2 and a 
constricted metaconid on lower milk teeth. It further differs from Aceratherium incisivum Kaup, 1832 in bearing higher crowned teeth and laterally expanded lingual cusps on upper cheek teeth but no medifossette on upper molars. Among aceratheriine chilotheres, this middle-sized taxon is closer to Aceratherium depereti Borissiak, 1927 from the early Vallesian of Sevastopol, Ukraine, Persiatherium rodleri Pandolfi, 2016 from the late Vallesian of Kopran (Maragheh, Iran), and to Persiatherium huadeensis (Qiu, 1979) from the late Miocene of Inner Mongolia (Qiu 1979; Pandolfi 2016), than to any other known species. These three species notably share with the chilothere from Küçükçekmece the presence of a lower cheek tooth row oblique with respect to the long axis of the corpus, the absence of a labial cingulum on upper premolars and of a constricted hypocone on $\mathrm{M} 1$, the usual presence of a lingual cingulid on lower cheek teeth, and the presence of a labial cingulid on lower molars. It can be differentiated from $A$. depereti in having lingually expanded lingual cusps and a lingual cingulum with V-shaped median incision on upper cheek teeth, and a developed ectolophid groove on lower cheek teeth, but no metaloph constriction on P2-P4, likewise P. rodleri and P. huadeensis (Borissiak 1927; Lu 2013; Pandolfi 2016).

However, it is distinct from $P$. rodleri in showing a straight lingual rim on the upper cheek tooth row, an antecrochet on upper molars, and a narrow postfossette but no labial cingulum on upper premolars, and from $P$. huadeensis in having a lingual cingulum and an antecrochet on upper premolars, but no pseudometaloph (Lu 2013; Pandolfi 2016). It can be further differentiated from both $P$. rodleri and $P$. huadeensis thanks to the presence of lower crowns, of a lingual bridge (appearing with wear) on P2, of a constricted protocone on P3-4, of a long metaloph on M1, and of a straight ectoloph on M1-2.

To sum up, morphological comparison allows for referring unambiguously this taxon to Persiatherium Pandolfi, 2016, so far documented in the Vallesian of Iran and Inner Mongolia (Pandolfi 2016), but it seems to have no closer affinities to $P$. rodleri than to $P$. huadeensis. Therefore, pending a revision of Eastern Mediterranean Vallesian aceratheriines, we choose to refer to it as Persiatherium sp.

Suborder ANCYLOPODA Cope, 1889

Superfamily CHALICOTHERIOIDEA Gill, 1872

Family CHALICOTHERIIDAE Gill, 1872

Subfamily CHALICOTHERIINAE Gill, 1872

Genus Kalimantsia Geraads, Spassov \& Kovachev, 2001

TyPE AND ONLY SPECIES. - Kalimantsia bulgarica Geraads, Spassov \& Kovachev, 2001 by original designation (Geraads et al. 2001: 596).

Kalimantsia sp.

(Fig. 4)

Chalicotherium goldfussi - Nicolas 1978: 456.
MATERIAL EXAMINED. - MNHN.F.TRQ670, left M2 (lingual fragment); TRQ671, right $\mathrm{M}$ fragment (protocone); TRQ669, phalanx II, right digit 4 (hand).

\section{COMPARATIVE DESCRIPTION \\ Upper dentition}

The upper molar MNHN.F.TRQ670 is broken, lacking most of the labial part (Fig. 4A). Yet, it was probably as wide as long in occlusal view (estimated dimensions: $\mathrm{W}=39.0$; $\mathrm{L}=41.0$ ), as usual in Chalicotheriinae (except Kalimantsia from the late Miocene of Bulgaria; Geraads et al. 2001) but contrary to Schizotheriinae and Kalimantsia (molars more elongated mesio-distally; Anquetin et al. 2007). A dilambdodont pattern is still discernable for the ectoloph (forming a W-shaped shearing crest in occlusal view), allowing for a referral to Chalicotheriidae (Coombs 1989). Lingual cusps are almost unworn. In occlusal view, the anterior side is convex and oblique distolingually, with a protocone much displaced distally with respect to the paracone. The former is located at mid-length of the tooth, as in Anisodon sp. from Vathylakkos (Bonis et al. 1995; Anquetin et al. 2007). The protoloph is low and thin, running only from the mesiolabial edge to the small paraconule, and then interrupted lingually, contrary to what occurs in Schizotheriinae. The protocone is totally isolated from other cusps in TRQ670 and TRQ671, as in all Chalicotheriinae. The lingual opening of the deep and wide median valley coincides with a concave inflection of the occlusal outline, as observed in all molars of Kalimantsia (Geraads et al. 2001). There is no lingual cingulum (TRQ670 and TRQ671). The metaloph is transversely oriented. Yet, the hypoconule is located distolabially with respect to the hypocone. The hypocone and hypoconule are equally developed and separate by a shallow groove at this early stage of wear. The short crest distolabially oriented running from the hypocone (posthypocrista) would confer a crescent-like shape to the metaloph at more advanced stages of wear, as in M2-M3s of Kalimantsia (Geraads et al. 2001). The postfossette is deep and narrow transversely, crescent-like in occlusal view and it opens distolabially. The distal cingulum is low and restricted to the bottom of the distal valley.

\section{Phalanx}

The phalanx MNHN.F.TRQ669 (Fig. 4A-D) is fully developed and belongs to an adult individual (fused epiphyses). The proximal facets are biconcave and elongate sagittally (Fig. 4D). They are separated by a smooth ridge and forming a c. $60^{\circ}$ angle in plantar view, which allows for identifying it as a phalanx II (only one proximal facet on the phalanx I whereas the phalanx III is a claw in chalicotheriids; Coombs 1989). There is no trace for coalescence with the phalanx I (thus forming a "duplex"), which discards any referral to Schizotheriinae (see Coombs 1989; Saraç \& Sen 2005). On the other hand, such morphology matches that of most Chalicotheriinae. The shaft is long, transversely compressed (Fig. $4 \mathrm{C})$, and symmetrical in anterior view $(\mathrm{L}=54.5$; $\mathrm{APD}=$ 48.5 ; $\mathrm{TD}=31$ ). These features are consistent with a phalanx 


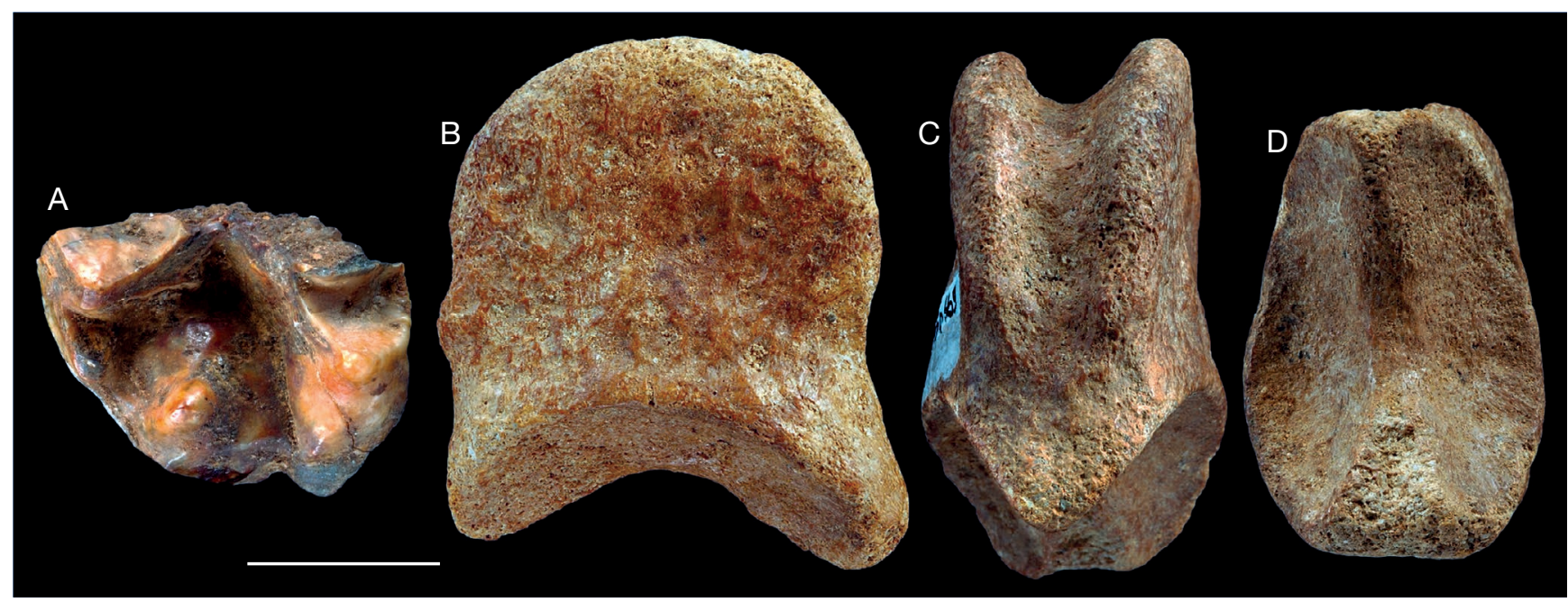

FIG. 4. - Tapiromorph perissodactyls from the upper Miocene locality of Küçükçekmece, Thrace, Turkey, Kalimantsia sp.: A, TRQ670, left M2 in occlusal view; B-D, TRQ669, phalanx II, right digit 4 (hand) in medial (B), anteroproximal (C), and posterior views (D). Scale bar: $20 \mathrm{~mm}$.

II from the manus, as hind limb phalanges are much shorter proximodistally in chalicotheriids, and more particularly in chalicotheriines (Coombs 1989; Guérin 2012). The distal facet is concave transversally, with a deep U-shaped profile, and regularly convex dorso-ventrally (Fig. 4B). When compared to the mounted hand of Anisodon grande from Sansan (Guérin 2012: fig 5), TRQ669 best matches the second phalanx of a right digit 4 .

\section{DISCUSSION}

The isometric dimensions of the upper molar (not elongated mesiodistally), the presence of an interrupted protoloph on it, and the absence of a duplex (unfused phalanx) allow for discarding the occurrence of a schizotheriine chalicotheriid in Küçükçekmece. On the other hand, all these features are observed in the chalicotheriines Chalicotherium, Anisodon, and Butleria (Zapfe 1989; Bonis et al. 1995; Anquetin et al. 2007; Guérin 2012). Molars are more elongate mesio-distally in the chalicotheriine Kalimantsia (M2 of the holotype: 43*37; Geraads et al. 2001) and in all schizotheriines (e.g., Ancylotherium; Geraads et al. 2001). The relative size of the dental-postcranial chalicothere remains is compatible, so that a single chalicotheriine taxon may occur in Küçükçekmece.

The presence of a paraconule on the M2 from Küçükçekmece discards any referral to Anisodon sivalense among chalicotheriines (Anquetin et al. 2007). The protoloph is extremely reduced with respect to M2s of Chalicotherium goldfussi from La Grive and Anisodon grande from Sansan (Anquetin et al. 2007). The distally-displaced position of the protocone is consistent with what is observed in both Anisodon sp. from Vathylakkos and Kalimantsia (Geraads et al. 2001; Anquetin et al. 2007). The presence of a well-developed hypoconule, of a crescent-like metaloph, of a disto-labially oriented narrow post-fossette, and of a lingual inflection in occlusal view concur to a referral to Kalimantsia bulgarica, even if the tooth from Küçükçekmece is less elongated mesio-distally than the M2 from the holotype of Kalimantsia.

\section{GENERAL DISCUSSION}

The occurrence of Kalimantsia (i.e. a chalicotheriine) in Küçükçekmece, Turkish Thrace, contrasts with the Anatolian chalicotheriid record, mostly consisting of schizotheriines (see Geraads et al. 2001), with the notable exception of Akkasdağ1 where only a chalicotheriine of uncertain affinities is recognized (Geraads et al. 2011; Chen et al. 2012). On the other hand, it substantiates the record of Kalimantsia, previously restricted to the type locality Kalimantsi-Pehsata, in SW Bulgaria, close to Greece, c. $250 \mathrm{~km}$ away from Küçükçekmece, and considered late Miocene in age ("MN11/12?"; Geraads et al. 2001). This new record allows notably for the first recognition of a postcranial remain (a second unfused phalanx) for this taxon. In middle and early late Miocene faunas from the Old World, Chalicotheriinae are often associated with other forest-dwellers and water-dependent mammals, such as tragulid ruminants, deinotheriid proboscideans, or castorid rodents (Bonis et al. 1999; Geraads et al. 2001; Guérin 2012). With no surprise, the Küçükçekmece fauna comprises Dorcatherium, Deinotherium, and Steneofiber (Sen 2016b; Tassy 2016; Kostopoulos \& Sen 2016).

As a whole the rhinocerotid assemblage of Küçükçekmece is characteristic for the late Miocene interval (late Vallesian+early Turolian), especially due to the co-occurrence of small and slender individuals of Ceratotherium neumayri (late VallesianTurolian; e.g., Antoine et al. 2012), of a brachydont "chilothere" (Persiatherium sp.; c. 9 Ma, Vallesian; Pandolfi 2016), and of a true chilothere related to Chilotherium schlosseri (upper Vallesian; Vangengeim \& Tesakov 2013) and its junior synonym C. kowalevskii (upper Vallesian; Vangengeim \& Tesakov 2013). This is in total agreement with the biostratigraphical age of Küçükçekmece, estimated to be correlated with the late Vallesian MN10 zone (Sen 2016a).

The faunal composition is quite distinctive between Küçükçekmece West and Küçükçekmece East, respectively, in terms of specimen abundance among aceratheriine rhinocerotids (Per- 
siatherium: seven / six; Chilotherium schlosseri: sixteen / four), but also regarding the rhinocerotine Ceratotherium neumayri and the chalicotheriine Kalimantsia sp., only documented in Küçükçekmece West. Also noteworthy is the occurrence in Küçükçekmece West of a reworked specimen of an early diverging rhinocerotid (Ronzotherium sp.), undoubtedly Oligocene in age, and thus reworked in the Küçükçekmece fauna.

\section{Acknowledgements}

The authors are grateful to Prof. Dr. Mehmet Sakınç for allowing us to study the specimens of the ITU collections, to Philippe Loubry (CR2P, MNHN) for the photographs of illustrated specimens. The authors warmly thank the reviewers, Lu Xiaokang and Luca Pandolfi, for their wise, thorough, and constructive comments and addings on a previous version of the manuscript. This is ISEM publication $\mathrm{n}^{\circ} 2016-079$.

\section{REFERENCES}

Agustí J. \& ANTÓN M. 2002. - Mammoths, sabretooths and hominids. Columbia University Press, New York, 313 p.

Anquetin J., Antoine P.-O. \& TASsy P. 2007. - Middle Miocene Chalicotheriinae (Mammalia, Perissodactyla) from France, with a discussion on chalicotheriine phylogeny. Zoological Journal of the Linnean Society 151: 577-608.

AnToine P.-O. 2002. - Phylogénie et évolution des Elasmotheriina (Mammalia, Rhinocerotidae). Mémoires du Muséum national d'Histoire naturelle 188, $359 \mathrm{p}$.

Antoine P.-O. \& SARAÇ G. 2005. - Rhinocerotidae (Mammalia, Perissodactyla) from the late Miocene of Akkașdağı, Turkey, in SEN S. (ed.), Geology, mammals and environments at Akkașdağı, late Miocene of Central Anatolia. Geodiversitas 27 (4): 601-632.

Antoine P.-O., Ducroce S., Marivaux L., Chaimanee Y., CroCHET J.-Y., JAEger J.-J. \& Welcomme J.-L. 2003a. — Early rhinocerotids (Mammalia: Perissodactyla) from South Asia and a review of the Holarctic Paleogene rhinocerotid record. Canadian Journal of Earth Sciences 40: 365-374.

Antoine P.-O., Duranthon F. \& Welcomme J.-L. 2003b. Alicornops (Mammalia, Rhinocerotidae) dans le Miocène supérieur des Collines Bugti (Balouchistan, Pakistan): implications phylogénétiques. Geodiversitas 25 (3): 575-603.

Antoine P.-O., Downing K. F., CROCHET J.-Y., DuRAnthon F., FlynN L.J., Marivaux L., Métais G., Rajpar A.R. \& Roohi G. 2010. - A revision of Aceratherium blanfordi Lydekker, 1884 (Mammalia: Rhinocerotidae) from the early Miocene of Pakistan: postcranials as a key. Zoological Journal of the Linnean Society 160: 139-194. http://dx.doi.org/10.1111/j.1096-3642.2009.00597.x

Antoine P.-O., Orliac M. J., Albayrak E., Ulusoy I., en E., ÇubukÇu E., Atici G., Aydar E. \& Sen S. 2012. - A Rhinocerotid Skull Cooked-to-Death in a 9.2 Ma-old Ignimbrite Flow of Turkey. PLoS ONE7 (11): e49997. http://dx.doi.org/10.1371/ journal.pone.0049997

AYMARD A. 1854. - Acquisitions d'ossements fossiles trouvés à Sainzelle, commune de Polignac; aperçu descriptif sur ce curieux gisement et détermination des espèces fossiles qu'il renferme. Annales de la Société d'Agriculture, Sciences, Arts et Commerce du Puy 18: 51-54.

BECKER D. 2009. - Earliest record of rhinocerotoids (Mammalia: Perissodactyla) from Switzerland: systematics and biostratigraphy. Swiss Journal of Geosciences 102: 489-504. http://dx.doi. org/10.1007/s00015-009-1330-4

Becker D., Antoine P.-O. \& Maridet O. 2013. - A new genus of
Rhinocerotidae (Mammalia, Perissodactyla) from the Oligocene of Europe. Journal of Systematic Palaeontology 11 (8): 947-972. http://dx.doi.org/10.1080/14772019.2012.699007

BeLIAJEVA E. I. 1954. - New rhinoceros remains from Kazakhstan. Travaux de l'Institut Paléozoologique de l'Académie des Sciences de l'URSS, Moscow 47: 44-54 (in Russian).

Bonis L. De, Bouvrain G., Koufos G. \& Tassy P. 1995. — Un crâne de chalicothère (Mammalia, Perissodactyla) du Miocène supérieur de Macédoine (Grèce) : remarques sur la phylogénie des Chalicotheriinae. Palaeovertebrata 24: 135-176.

Bonis L. DE, Bouvrain G. \& Koufos G. D. 1999. — Palaeoenvironments of late Miocene primate localities in Macedonia, Greece, in Agustí J., Rook L. \& Andrews P. (eds), The Evolution of Neogene Terrestrial Ecosystems in Europe. Cambridge University Press, Cambridge: 415-435.

BORISSIAK A. A. 1927. - Aceratherium depereti n. sp. from the Jilančik beds. Bulletin de l'Académie des Sciences de l'URSS 21: 769-786 (in Russian).

BRUNET M. 1979. - Les grands mammiferes chefs de file de limmigration oligocène et le problème de la limite Eocène-Oligocène en Europe. Fondation Singer-Polignac, Paris, 281 p.

Chen S. K., Deng T., Pang L. B., He W. \& Chen S. Q. 2012. A juvenile skull of Ancylotherium (Mammalia, Perissodactyla, Chalicotheriidae) from the Pliocene of China. Geobios 45 (6): 527-534. http://dx.doi.org/10.1016/j.geobios.2012.06.002

Coombs M. C. 1989. - Interrelationships and diversity in the Chalicotheriidae, in Prothero D. R. \& SCHOCH R. M. (eds), The Evolution of Perissodactyls. Oxford University Press, New York: 438-457.

Dashzeveg D. 1991. - Hyracodontids and rhinocerotids (Mammalia, Perissodactyla, Rhinocerotoidea) from the Paleogene of Mongolia. Palaeovertebrata 21: 1-84.

Fortelius M., Heissig K., Saraç G. \& Sen S. 2003. - Rhinocerotidae (Perissodactyla), in ForTelius M., KAPPELMAN J., Sen S. \& Bernor R. L. (eds), Geology and Paleontology of the Miocene Sinap Formation, Turkey. Columbia University Press, New York, 282-307.

GERAADS D. 1988. - Révision des Rhinocerotinae (Mammalia) $\mathrm{du}$ Turolien de Pikermi. Comparaison avec les espèces voisines. Annales de Paléontologie 74: 13-41.

GERAADS D. 1994. — Les gisements de mammiferes du Miocène supérieur de Kemiklitepe, Turquie: 4. Rhinocerotidae. Bulletin du Muséum national d'Histoire naturelle, Paris, 4ème série, section C, 16: 81-95.

GeraAds D., Spassov N. \& Kovachev D. 2001. - New Chalicotheriidae (Perissodactyla, Mammalia) from the Late Miocene of Bulgaria. Journal of Vertebrate Paleontology 21 (3): 596-606. http://dx.doi.org/10.1671/0272-4634(2001)021 [0596:NCPMFT]2.0.CO;2

Geraads D., Spassov N., Hristova L., Markov G.N. \& Tzankov T. 2011. - Upper Miocene mammals from Strumyani, SouthWestern Bulgaria. Geodiversitas 33 (3): 451-484. http://dx.doi. org/10.5252/g2011n $3 \mathrm{a} 3$

GiaOURTSAKIS I. 2009. - The Late Miocene Mammal Faunas of the Mytilinii Basin, Samos Island, Greece: New Collection. 9. Rhinocerotidae. Beiträge zur Paläontologie 31: 157-187.

GRAY J. E. 1867. - Observations on the preserved specimens and skeletons of the Rhinocerotidae in the collections of the British Museum and Royal College of Surgeons, including the description of three new species. Proceedings of the Zoological Society of London: 1003-1022.

GuÉRIN C. 2012. - Anisodon grande (Perissodactyla, Chalicotheriidae) de Sansan, in PeIGNÉ S. \& Sen S. (eds), Mammiferes de Sansan. Muséum national d'Histoire naturelle, Paris (Mémoires du Muséum national d'Histoire naturelle; 203): 279-315.

HeIsSIG K. 1972. — Paläontologische und geologische Untersuchungen im Tertiär von Pakistan. 5. Rhinocerotidae (Mamm.) aus den unteren und mittleren Siwalik-Schichten. Bayerische 
Akademie der Wisseschaften, Mathematisch-Naturwissenschaftliche Klasse Abhandlungen 152: 1-112.

HEISSIG K. 1975. — Rhinocerotidae aus dem Jungtertiär Anatoliens. Geologisches Jahrbuch B 15: 145-151.

KAYA T. \& HeISSIG K. 2001. — Late Miocene rhinocerotids (Mammalia) from Yulaflı (Corlu-Thrace/Turkey). Geobios 34 (4): 457-467. http://dx.doi.org/10.1016/S0016-6995(01)80009-7

Kostopoulos D. S. \& Sen S. 2016. — Suidae, Tragulidae, Giraffidae, and Bovidae, in SEN S. (ed.), Late Miocene mammal locality of Küçükçekmece, European Turkey. Geodiversitas 38 (2): 273-298 (this volume). http://dx.doi.org/10.5252/g2016n2a8

Koufos G. D. \& Sen S. 2016. - Equidae, in Sen S. (ed.), Late Miocene mammal locality of Küçükçekmece, European Turkey. Geodiversitas 38 (2): 225-243 (this volume). http://dx.doi. org/10.5252/g2016n2a5

LOM N., Ülgen S. C., SAKINÇ M. \& ŞENGÖR A. M. C. 2016. — Geology and stratigraphy of Istanbul region, in SEN S. (ed.), Late Miocene mammal locality of Kücükçekmece, European Turkey. Geodiversitas 38 (2): 175-195 (this volume). http://dx.doi.org/10.5252/g2016n2a3

LU X.-K. 2013. - A juvenile skull of Acerorhinus yuanmouensi (Mammalia: Rhinocerotidae) from the Late Miocene hominoid fauna of the Yuanmou Basin (Yunnan, China). Geobios 46 (6): 539-548. http://dx.doi.org/10.1016/j.geobios.2013.10.001

Malik A. \& NAFIZ H. 1933. - Vertébrés fossiles de Küçük Çekmece. Bulletin de la Faculté des Sciences de l'Université d'Istanbul 8: 1-119.

Ménouret B. \& Guérin C. 2009. — Diaceratherium massiliae nov. sp. des argiles oligocènes de Saint-André et Saint-Henri à Marseille et de Les Milles près d'Aix-en-Provence (SE de la France), premier grand Rhinocerotidae brachypode européen. Geobios 42 (3): 293-327. http://dx.doi.org/10.1016/j.geobios.2008.10.009

Mirzai AtaAbadi M. M., Liu L. P., EROnen J. T., Bernor R. L. \& ForTELIUS M. 2013. - Continental-scale patterns in Neogene mammal community evolution and biogeography: a Europe-Asia Perspective, in Wang X., FlYNN L. J. \& ForTElius M. (eds), Fossil Mammals of Asia. Neogene Biostratigraphy and Evolution. Columbia University Press, New York: 629-638.

NicOLAS J. 1978. — Un nouveau gisement de vertébrés dans le Chersonien: Kutchuk-Tchekmedje Ouest (Thrace turque). Comptes rendus de l'Académie de Sciences 287D: 455-458.

PANDOlFi L. 2016. — Persiatherium rodleri, gen. et sp. nov. (Mammalia, Rhinocerotidae) from the Upper miocene of Maragheh (Northwestern Iran). Journal of Vertebrate Paleontology 36 (1): e1040118. http://dx.doi.org/10.1080/02724634.2015.1040118
PaVlow M. A. 1913. - Mammifères Tertiaires de la Nouvelle Russie. 1ère Partie: Artiodactyla Perissodactyla (Aceratherium kowalevskii n. s.). Nouveaux mémoires de la Société impériale des naturalistes de Moscou 17: 1-67.

Peigné S. 2016. - Carnivora, in Sen S. (ed.), Late Miocene mammal locality of Küçükçekmece, European Turkey. Geodiversitas 38 (2): 197-224 (this volume). http://dx.doi.org/10.5252/g2016n2a4

QIU Z.-D. 1979. - Some mammalian fossils from the Pliocene of Inner Mongolia and Gansu (Kansu). Vertebrata PalAsiatica 17: 222-235 (222-233 in Chinese; 234-235 in English).

SARAÇ G. \& SEN S. 2005. - Chalicotheriidae (Mammalia, Perissodactyla) from the late Miocene of Akkasdag1, Turkey, in SEN S. (ed.), Geology, mammals and environments at Akkașdağı, late Miocene of Central Anatolia. Geodiversitas 27 (4): 591-600.

SAYAR A. M. 1953. - Istanbul civarinda üst Miosen omurgalılarına ait yeni müşahedeler. Bulletin de la Faculté des Sciences de l'Université d'Istanbul 9: 9-12.

SEN S. 2016a. - Historical background, in SEN S. (ed.), Late Miocene mammal locality of Küçükçekmece, European Turkey. Geodiversitas 38 (2): 153-173 (this volume). http://dx.doi. org/10.5252/g2016n2a2

SEN S. 2016b. - Rodents, lagomorphs and insectivores, in SEN S. (ed.), Late Miocene mammal locality of Küçükçekmece, European Turkey. Geodiversitas 38 (2): 299-314 (this volume). http:// dx.doi.org/10.5252/g2016n2a9

TAssy P. 2016. - Proboscidea, in SEN S. (ed.), Late Miocene mammal locality of Küçükçekmece, European Turkey. Geodiversitas 38 (2): 261-271 (this volume). http://dx.doi.org/10.5252/g2016n2a7

Uhlig U. 1999. - Die Rhinocerotidae (Mammalia) aus der unteroligozänen Spaltenfüllung Möhren 13 bei Treuchtlingen in Bayern. Verlag der Bayerischen Akademie der Wissenschaften Abhandlungen 170, $254 \mathrm{p}$.

VAngengeim E. \& Tesakov A. S. 2013. — Late Miocene Mammal Localities of Eastern Europe and Western Asia: Toward Biostratigraphic Synthesis, in WANG X.-M., FLYNN, L. J. \& ForTELIUS M. (eds), Fossil Mammals of Asia. Neogene Biostratigraphy and Chronology. Columbia University Press, New York, 521-537.

YALÇINLAR I. 1954. - Les gisements de mammiferes et d'autres vertébrés fossiles de la Turquie. Comptes Rendus Congrès géologique international, Alger 15: 139-147.

ZAPFE H. 1989. - Chalicotherium goldfussi KAUP aus dem Vallesien vom Höwenegg im Hegau (Südwestdeutschland). Andrias 6: $117-126$ 